\title{
Atrial natriuretic factor and C-type natriuretic peptide induce retraction of human thyrocytes in monolayer culture via guanylyl cyclase receptors
}

\author{
D F Sellitti ${ }^{1}$, C Lagranha ${ }^{1,2}$, G Perrella ${ }^{3}$, F Curcio ${ }^{3}$ and S Q Doi ${ }^{1}$ \\ ${ }^{1}$ Department of Medicine, Divisions of Endocrinology and Nephrology, Uniformed Services University of the Health Sciences, 4301 Jones Bridge Road, \\ A3060, Bethesda, MD 20814-4799, USA \\ ${ }^{2}$ Department of Biophysics and Physiology, Division of Endocrinology, University of Sao Paulo, Sao Paulo, Brazil \\ ${ }^{3}$ Dipartimento di Patologia e Medicina Sperimentale e Clinica, University of Udine, Udine, 33100, Italy \\ (Requests for offprints should be addressed to D F Sellitti)
}

\begin{abstract}
The natriuretic peptides signal through three receptor subtypes, of which two (NPR-A and NPR-B) are membrane-bound guanylyl cyclases for which the principal ligands are respectively atrial natriuretic factor (ANF) and C-type natriuretic peptide (CNP). In the human thyroid cell, a third receptor, NPR-C, has been implicated in the regulation of thyroglobulin, but functional roles for NPR-A and NPR-B have not yet been defined. In the present study we used RT-PCR to identify transcripts of all three receptor subtypes, both in human thyroid and in HTU-5 cells, a long-term culture of thyroid-derived cells. Both ANF and CNP induced a twofold increase in intracellular cGMP content in HTU-5 cells. Morphologic changes (a significant increase in cells of the retracted phenotype) were observed in ANF- and CNP-treated cells within 3 and $5 \mathrm{~h}$ of treatment respectively. Significant
\end{abstract}

increases in retracted cell number were induced by ANF and CNP, but not the NPR-C-specific ring-deleted ANF analog, C-ANF(4-23), during a 15-day treatment. All three natriuretic peptides, however, induced a small (15$20 \%)$ but significant $(P<0 \cdot 001)$ increase in DNA content per well. The stable analog of cGMP, 8-bromo-cGMP (8-BrcGMP; $1 \mathrm{mM}$ ), also increased the number of retracted HTU-5 cells, and was equipotent with the cAMP analog, 8-BrcAMP, in this effect. The cGMPdependent protein kinase inhibitor, KT5823, however, had no significant effect on the ANF-induced increase in numbers of retracted cells. These results suggest that the actions of NPR-A and NPR-B, functional receptors in the human thyroid cell, may in part be mediated by cGMP-induced alterations in the cytoskeleton.

Journal of Endocrinology (2002) 173, 169-176

\section{Introduction}

The natriuretic peptides (atrial natriuretic factor (ANF), brain natriuretic peptide (BNP), and C-type natriuretic peptide (CNP) (Levin et al. 1998)) have been proposed as a class of endocrine/autocrine regulatory factors in the mammalian thyroid gland (Hughes \& Sellitti 1991, Eggo \& Sheppard 1994, Bidey et al. 1999) on the basis of the co-expression of both natriuretic peptides and their receptors (NPRs) in thyroid follicular cells of several species (Sellitti \& Hughes 1990, Tseng et al. 1990, Hughes \& Sellitti 1991, Sellitti et al. 1992, Sellitti \& Doi 1994, 1999). Two of the three subtypes of NPR, NPR-A and NPR-B, are membrane guanylyl cyclases that induce intracellular cGMP formation upon binding natriuretic peptide (Chinkers et al. 1989, Koller et al. 1991, Garbers \& Lowe 1994). The other, NPR-C, is coupled to adenylyl cyclase in many cell systems, but the mechanism linking this receptor to cAMP remains controversial
(Anand-Srivastava \& Trachte 1993, Murthy \& Makhlouf 1999, Sellitti et al. 2001). ANF and CNP are the principal ligands for NPR-A and NPR-B respectively (Lowe et al. 1989, Schultz et al. 1989). NPR-C, however, is relatively less selective as to natriuretic peptide structure, and binds both ANF and CNP with similar affinity (Fuller et al. 1988). NPR-C was the first natriuretic peptide receptor to be associated with the regulation of a specific thyroid function, following the observation that ANF suppresses thyroglobulin production in human thyrocyte cultures (Tseng et al. 1990). Furthermore, it was established that the thyroglobulin suppression correlated closely with an inhibition of intracellular cAMP production by ANF.

To date, however, no specific function has been identified specifically with either the NPR-A or NPR-B receptor in thyroid cells, despite several studies demonstrating their presence in thyrocytes of rat and porcine origin (Hughes \& Sellitti 1991, Sellitti \& Doi 1999). Nonetheless, previous reports linking cGMP generation to 
specific functions in the thyroid cell would appear to support a role for NPR guanylyl cyclase/cGMP signaling (Bocanera et al. 1997, Rasmussen et al. 1997). To evaluate further the role of NPR subtype in thyroid function, we have studied the expression of the three NPR subtypes in human thyroid and in HTU-5 cells, a long-term culture of human thyrocytes (Curcio et al. 1994). Human thyrocytes in culture exhibit distinctive morphologic changes in response to hormonal stimulation, including cytoplasmic retraction, a process in which the cytoplasm of monolayer cells is partially detached from the substrate, leaving only highly arborized processes in contact with the substrate and with neighboring cells (Westermark \& Porter 1982, Lamy et al. 1990, Taton et al. 1993, Asakawa et al. 1996). This process has been shown to be hormonally sensitive, with both thyrotropin and cAMP treatment effecting an increase in the retracted phenotype (Taton et al. 1993). In the present study, we have exploited the distinctive phenotype of these cells to examine the effects of subtypespecific natriuretic peptides (ANF, CNP, and C-ANF(423)) and their intracellular signaling systems, in thyroid cells of human origin.

\section{Materials and Methods}

\section{Reagents}

Rat ANF (ANF(99-126)), CNP-22, and C-ANF(4-23) were purchased from Peninsula Laboratories (Belmont, CA, USA). Thyroid-stimulating hormone (TSH) from bovine pituitary (2 IU/mg protein), 8-bromoguanosine 3,5'-cyclic monophosphate (8-BrcGMP) and 8-bromoadenosine 3,5'-cyclic monophosphate (8-BrcAMP) were obtained from Sigma Chemical, St Louis, MO, USA. KT5823 was obtained from Calbiochem (San Diego, CA, USA). Human thyroid, heart and kidney mRNA were purchased from Clontech (Palo Alto, CA, USA).

\section{Cell culture}

A clonal strain of human thyroid cells (HTU-5) was developed from normal human thyroid tissue and grown using methods previously reported (Curcio et al. 1994). In brief, normal thyroid tissue from pathological specimens was freed from adherent connective tissue, cut into small pieces, washed in $\mathrm{Ca}^{2+}$ - and $\mathrm{Mg}^{2+}$-free Hanks's balanced salt solution (HBSS) and digested with a solution consisting of $20 \mathrm{U} / \mathrm{ml}$ collagenase, $0.75 \mathrm{mg} / \mathrm{ml}$ trypsin, and $2 \%$ heat-inactivated dialyzed chicken serum, in $\mathrm{Ca}^{2+}-$ and $\mathrm{Mg}^{2+}$-free HBSS. Following a 2-h digestion, cell suspensions were seeded onto $100-\mathrm{mm}$ plastic culture dishes in a culture medium consisting of a modified F-12 medium as described earlier (Trusolino et al. 1998), and in which secondary cultures were passaged.

In the present study, HTU-5 cells were used between passages 9 and 16 . The purity and state of differentiation of these cells were assessed and compared with human thyroid and heart controls using RT-PCR for the expression of the thyroid-restricted genes Pax-8, thyrotropin receptor $(T S H-R)$, and thyroglobulin $(T g)$ as described below. Results indicated the partial de-differentiation of HTU-5 cells by passage 13, with the loss of TSH-R and Pax- 8 expression. Despite the loss of thyroid-specific gene expression, these cells retained the typical morphology of human thyrocytes in monolayer culture and their capacity for retraction, confirming that the cultures remained purely thyrocyte in nature, even after several passages.

The basic culture medium for these cells was Coon's F-12 medium (Sigma) modified by the addition of $\mathrm{MgCl}_{2}$ to a final concentration of $0.5 \mathrm{mM}, \mathrm{CaCl}_{2}$ to $1.1 \mathrm{mM}$ and glucose to $3.6 \mathrm{mM}$. The medium (Humed) was also supplemented with $5 \%$ fetal bovine serum, a five-hormone mixture (insulin, somatostatin, hydrocortisone, transferrin and glycyl-histidyl-lysine), and bovine hypothalamus and bovine pituitary (Pel Freez Biologicals, Rogers, AK, USA) extracts, as previously described (Curcio et al. 1994).

\section{cGMP assay}

Cells were plated randomly and evenly and grown to confluence in Humed medium in 24-well plates. At assay, growth medium was aspirated and culture wells received $0.4 \mathrm{ml}$ minimal essential medium (MEM) containing $1 \mathrm{mM} \mathrm{CaCl}_{2}, 1 \mathrm{mM} \mathrm{Mg}_{2} \mathrm{SO}_{4}, 1 \%$ bovine serum albumin, $0.5 \mathrm{mM}$ isobutylmethylxanthine, and either ANF or CNP $(0-1 \mathrm{mM})$. After a 20 -min incubation at $37^{\circ} \mathrm{C}$, medium was aspirated and wells received $0.5 \mathrm{ml}$ of a $0.1 \mathrm{M} \mathrm{HCl}$ solution containing $0.1 \mathrm{mM} \mathrm{CaCl}_{2}$, and these samples were stored at $-70{ }^{\circ} \mathrm{C}$ until required for determination of cGMP content by RIA (Biomedical Technologies, Staughton, MA, USA). All samples were diluted 1:5 in acetate buffer and acetylated before being assayed. Significant differences among treatment groups were determined using ANOVA followed by Dunnett's $t$-test with InStat software (GraphPad Software Inc., San Diego, CA, USA).

\section{Retracted cell count}

HTU-5 cells were plated randomly and evenly and grown to confluence in Humed medium in 24-well plates. After treatment (ANF, CNP, C-ANF(4-23), 8-BrcAMP or 8-BrcGMP), randomly selected fields from the center of each well were observed under low power $(10 \times$ objective) using a phase-contrast microscope (Olympus), and the total number of retracted cells in the field was counted. A cell was considered to be retracted if the cell body was refractile, with extensive cytoplasmic arborization in place of the normal flattened monolayer phenotype. Mean counts of retracted cells (retracted cells/field) were determined and analyzed for significant differences 
between treatment groups using non-parametric ANOVA and Dunn's test. Statistical tests were performed using Instat software.

\section{DNA assay}

Effects of natriuretic peptides on cell proliferation were determined by measuring the DNA content of HTU-5 cells grown in the presence of various natriuretic peptides in 24-well plates for retracted cell counting. After the cells had been washed with ice-cold HBSS, DNA was precipitated with $10 \%$ trichloroacetic acid, and the DNA content of each well was determined by colorimetric (diphenylamine) assay (Giles \& Myers 1965) and comparison with a standard curve of calf thymus DNA. Differences in DNA content between groups were compared using ANOVA with Instat software.

\section{PCR}

Polyadenylated (poly $(\mathrm{A})+$ ) mRNA was prepared from HTU-5 cells grown in plastic culture flasks using a Mini RiboSep Ultra mRNA isolation kit (Collaborative Biomedical Products, Bedford, MA, USA) according to the manufacturer's procedure. Human kidney and thyroid polyA + mRNA $(1 \mathrm{mg} / \mathrm{ml})$ were purchased from Clontech (Palo Alto, CA, USA). After reverse transcription using the display-Thermo-RT kit (Display Systems Biotech), cDNA $(2 \mu \mathrm{l})$ was used in each PCR reaction in a total volume of $50 \mu \mathrm{l}$. PCR amplification of the RT reaction product was accomplished using the following primers (bold bases represent the addition of $\mathrm{G}$ clamps and restriction sites to the $5^{\prime}$ ends of certain primers): NPR-A - sense AAAGACCCAGATAATCCCGAGTACT, antisense TTGCATGCTGGGGTCTTCGTTGTCA (450 bp); NPR-B - sense GGGTCGACCACCAGGTGTAT GCCCGAGAGCCA, antisense GGAAGCTTCCGTC CCGTCCACCAAATCTGCTT (670 bp); NPR-C sense AGCGGAACTGCTTCTTCACC, antisense GT CTCCGTTGGCATCTATGG (570 bp). To avoid any possibility of confusion with amplification of genomic DNA, the expected cDNA product for each NPR was chosen to span several intron/exon regions as follows: NPR-A, exons 3-6 of the human gene; NPR-B, exons 1-6 of the human gene; and NPR-C, exons $1-5$ of the bovine gene.

RT-PCR as described above was also used to assess thyroid-restricted gene expression in HTU-5 cells in comparison with human thyroid and human heart (Clontech) controls. Sequences for the $T g$ primers and TSH-R primers have been described by us previously (Sellitti et al. 1997, 2000). Pax-8 primers (sense TACT ACGAGACTGGCAGCATCC and antisense CTGCT GCTCTGTGAGTCAATGC) were designed from the
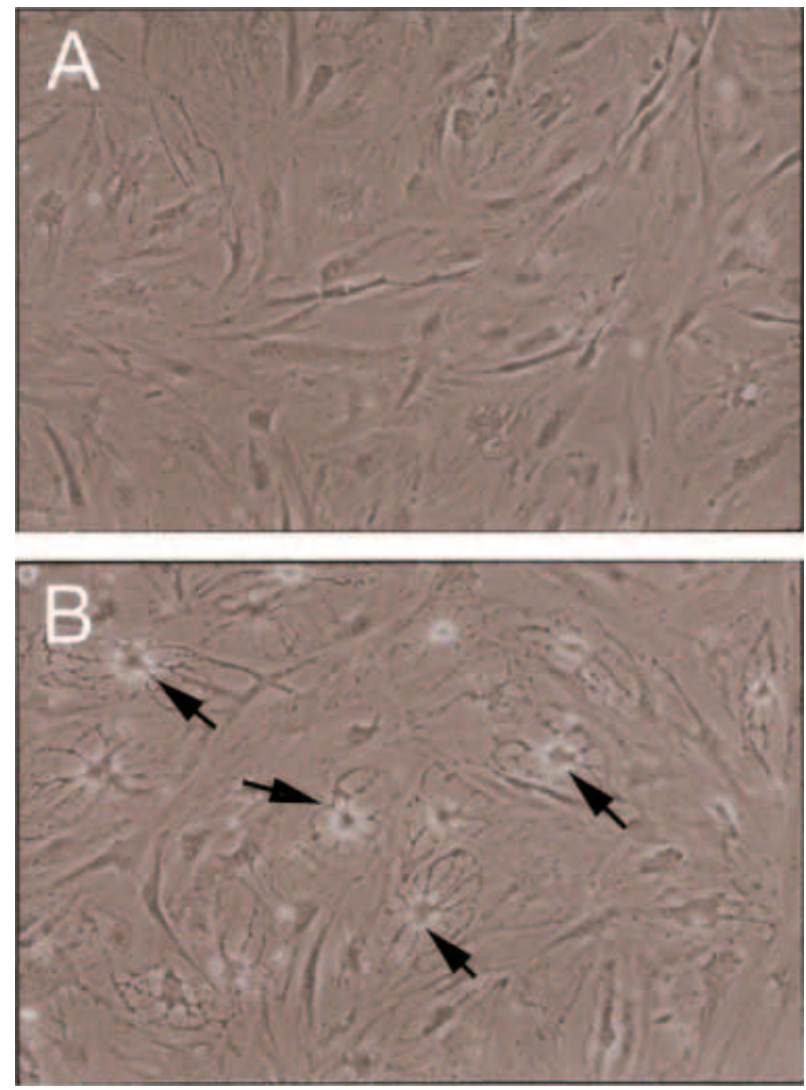

Figure 1 Phase-contrast photomicrographs of HTU-5 human thyrocytes in culture. (A) Field showing only cells with typical monolayer phenotype. (B) Field showing a high concentration of retracted cells (arrows).

mRNA sequence of human Pax-8 (GenBank accession number BC001060) using Gene Jockey software.

\section{Results}

In Humed medium, most HTU-5 cells assumed a flattened phenotype with a low nuclear:cytoplasmic ratio (Fig. 1A). Occasional cells, however, possessed a retracted phenotype (Fig. 1B, arrows), typified by their refractile appearance and the arborization of their cytoplasm, and could be induced in large numbers after hormonal treatment.

The results of RT-PCR for the three NPR subtypes in these cells and in whole human thyroid are shown in Figure 2. Human kidney served as a control. Transcripts for all three NPR subtypes were detected in both whole human thyroid and HTU-5 cells. Stimulation of cGMP production by NPR-specific ligands was used to establish the presence of functional NPR-A and NPR-B receptor protein in HTU-5 (Fig. 3). Basal cGMP content was close to the limits of detection of the cGMP RIA. Nevertheless, 


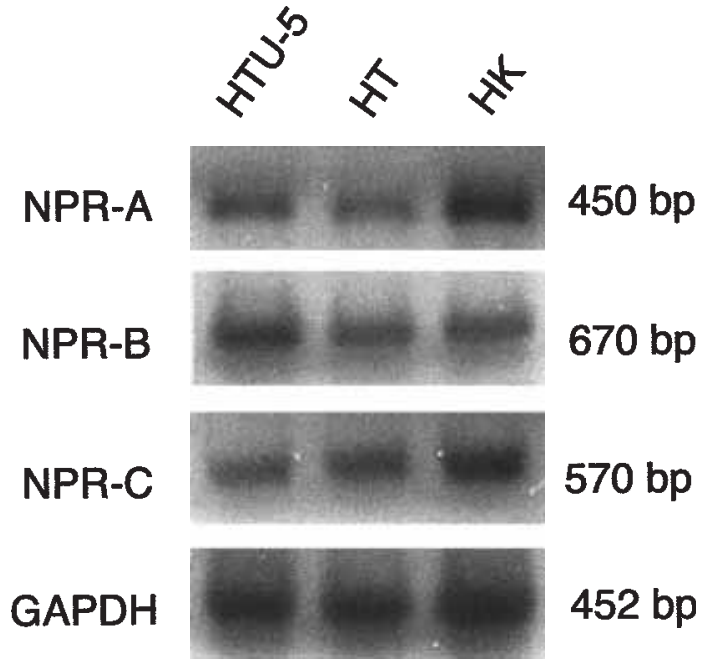

Figure 2 RT-PCR of NPR-A, NPR-B, and NPR-C in HTU-5 cells, human thyroid (HT) and human kidney (HK). Poly (A)+ mRNA was prepared as described in Materials and Methods, from HTU-5 cells grown in complete Humed medium. Human thyroid and human kidney mRNA were from Clontech.

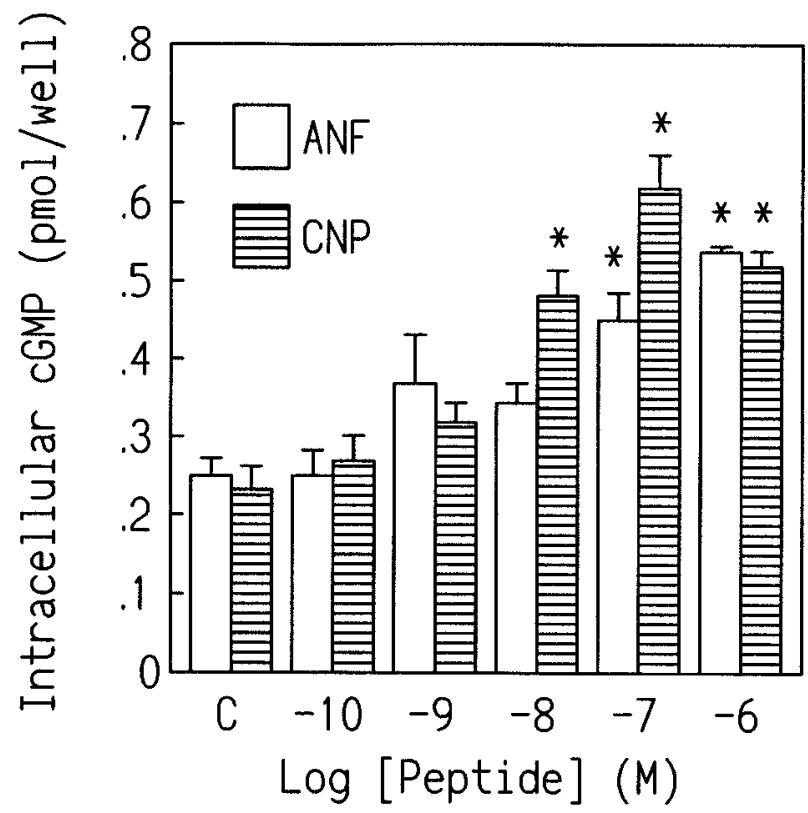

Figure 3 Effect of ANF and CNP on cGMP generation in HTU-5 cells. Cells were evenly plated into 24-well culture plates and grown to confluence in complete Humed medium before cGMP assay as described in Materials and Methods. Data points represent the mean of quadruplicate determinations \pm S.E.M. Statistical comparisons were made using ANOVA followed by Dunnett's $t$-test. ${ }^{*} P<0 \cdot 01$ compared with control.

in cells grown in complete Humed, a similar twofold maximal response in cGMP to stimulation with either ANF or CNP suggested the presence of similar concentrations of both guanylyl cyclase NPRs.

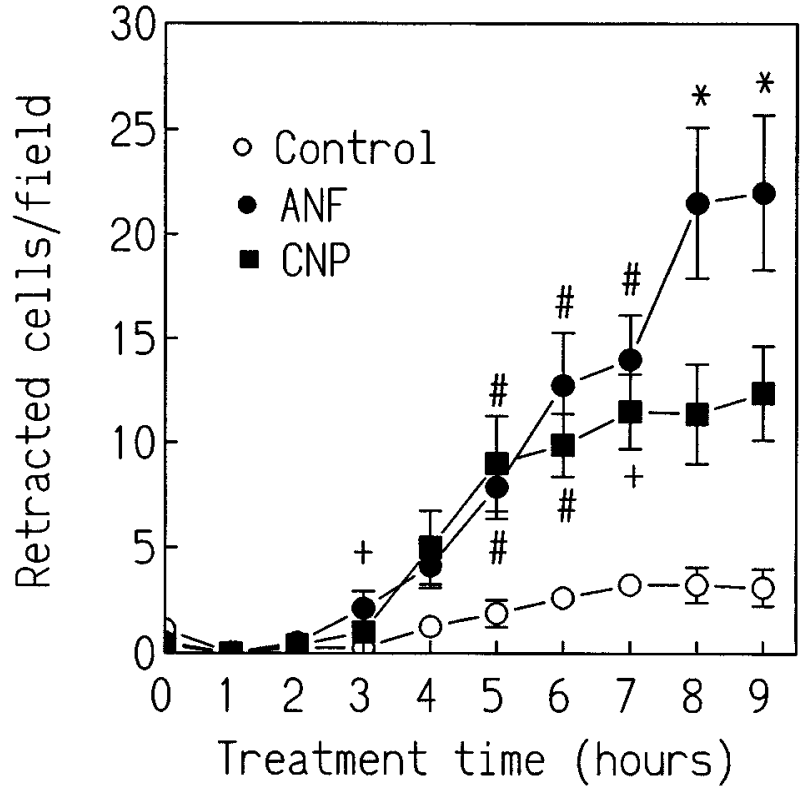

Figure 4 Time-course of ANF- and CNP-stimulated increase in retracted HTU-5 cells. HTU-5 cells in 24-well plates received Humed medium containing ANF $(1 \mu \mathrm{M}), \mathrm{CNP}(1 \mu \mathrm{M})$ or vehicle (control), and retracted cells were counted immediately (5 min) and at 1 -h intervals after treatment. Data represent mean \pm S.E.M. of eight wells for each treatment group. Treatments were compared using non-parametric ANOVA and Dunn's Multiple Comparisons Test. $+P<0 \cdot 05, \# P<0 \cdot 01,{ }^{*} P<0.001$ compared with control (shown above ANF values and below CNP values).

Figure 4 demonstrates that significant increases in retracted cell number were evident after treatment of HTU-5 cells with either $1 \mathrm{mM}$ ANF (rat ANF(99-126)) or $1 \mathrm{mM}$ CNP (CNP-22). Although refeeding with fresh medium increased the retracted cell number in all groups within $4 \mathrm{~h}$, numbers of retracted cells in the ANF- and CNP-treated groups respectively reached approximately seven- and fourfold the control value by $9 \mathrm{~h}$ of treatment. In a separate experiment to determine the long-term effects of natriuretic peptides on cell retraction, HTU-5 cells were treated with rat ANF(99-126), CNP-22, or C-ANF(4-23) for a period of 15 days, and counts of retracted cells were made daily (Fig. 5). After $24 \mathrm{~h}$, both ANF (Fig. 5A) and CNP (Fig. 5B), but not C-ANF(4-23) (Fig. 5C), increased the number of retracted cells significantly above control. However, whereas retracted cells in the ANF-treated group returned toward control numbers within 5 days, cell retraction in the CNP-treated group declined at a much slower rate and remained significantly greater than control through day 13. Occasionally (e.g. treatment day 8), counts showed little difference between the retraction of control and CNP-treated cells, reflecting the lability of the retracted phenotype. Throughout the 15-day treatment, the NPR-C specific natriuretic peptide analog failed to increase cell retraction above 

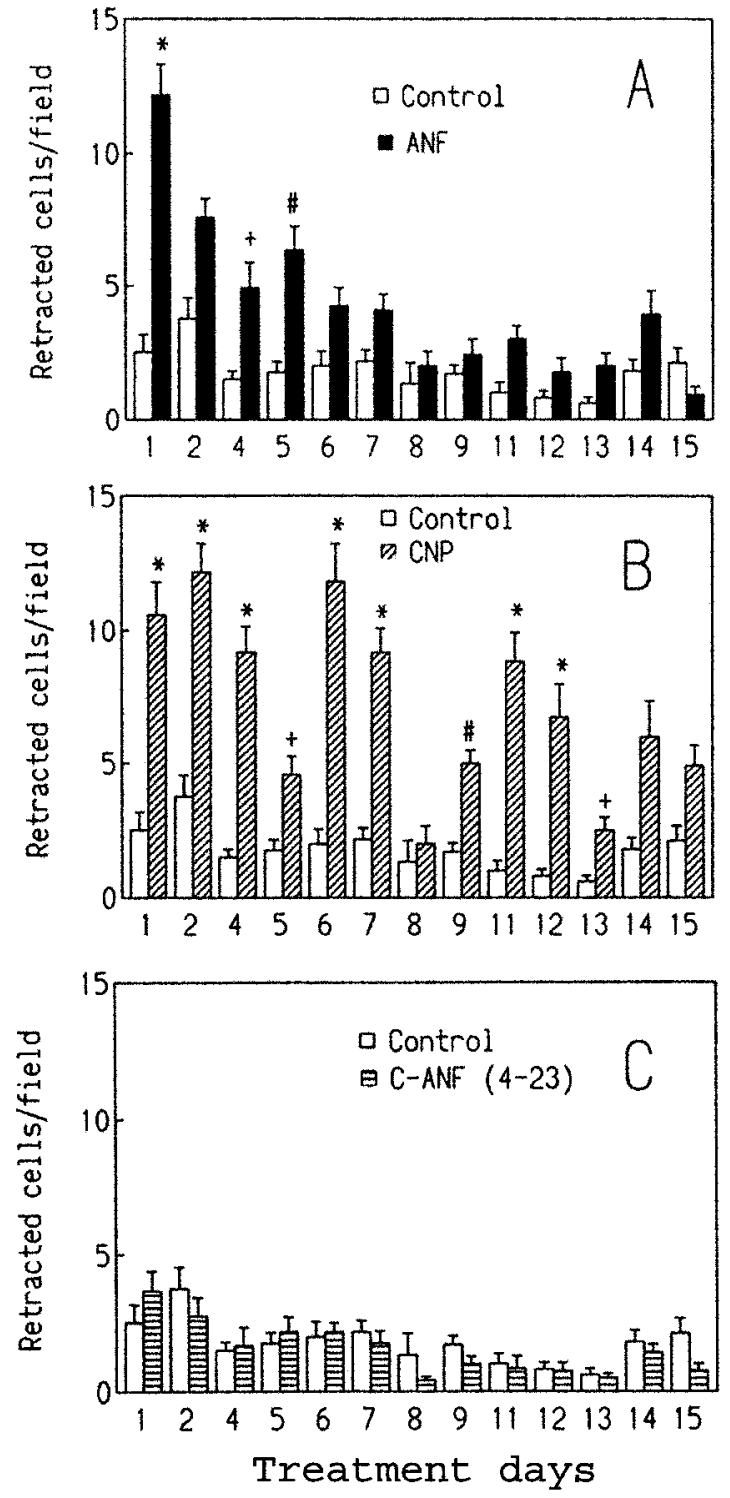

Figure 5 Long-term effects of natriuretic petides on numbers of retracted HTU-5 cells. HTU-5 cells were grown to confluence in 24-well plates and received a final concentration of $1 \mu \mathrm{M}$ rat ANF(99-126) (A), $1 \mu \mathrm{M}$ CNP-22 (B) or $1 \mu \mathrm{M}$ C-ANF(4-23) (C) in complete Humed for 15 days. Control cells received only vehicle in Humed, and are shown in each panel as open bars. Data represent mean \pm S.E.M. of 12 wells for each treatment group. Treatment medium was replenished every other day. Treatments were compared using non-parametric ANOVA and Dunn's Multiple Comparisons Test. $+P<0 \cdot 05, \# P<0 \cdot 01,{ }^{*} P<0 \cdot 001$ compared with control.

control values at any time (Fig. 5C). After treatment, a diphenylamine assay showed a small but significant $(P<0 \cdot 001)$ increase in DNA content/well with each of the three natriuretic peptides compared with control (control $=0 \cdot 38 \pm 0 \cdot 01 \mathrm{mg} /$ well $; \quad A N F=0 \cdot 46 \pm 0 \cdot 01 \mathrm{mg} /$

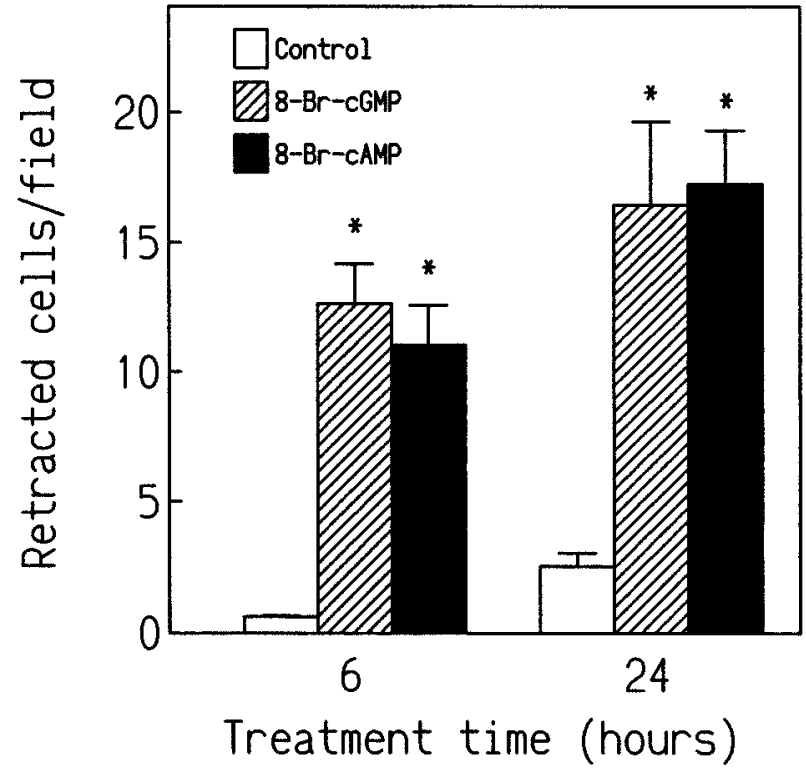

Figure 6 Effects of 8-BrcGMP and 8-BrcAMP on numbers of retracted HTU-5 cells. HTU-5 cells were plated into 24 -well plates and received either $1 \mathrm{mM}$ 8-BrcGMP or $1 \mathrm{mM}$ 8-BrcAMP in complete Humed medium for either 6 or $24 \mathrm{~h}$. Control cells received only vehicle in Humed. Data represent mean \pm S.E.M. of 12 wells for each treatment group. Treatments were compared using non-parametric ANOVA and Dunn's Multiple Comparisons Test. ${ }^{*} P<0 \cdot 001$ compared with control.

well; C-ANF(4-23) $=0.44 \pm 0 \cdot 0 \mathrm{mg} /$ well; $\mathrm{CNP}=0 \cdot 46 \pm$ $0 \cdot 01 \mathrm{mg} /$ well $)$.

The cell retraction response to both ANF and CNP, but not C-ANF(4-23), implied a role for cGMP in thyrocyte retraction. Figure 6 compares the effects of the stable analog of cGMP, 8-BrcGMP, with those of 8-BrcAMP on retracted cell number. Both cyclic nucleotide analogs resulted in significant increases in retracted cell count above control, and these were evident within $6 \mathrm{~h}$ of treatment (Fig. 6).

Because activation of cGMP-dependent protein kinases (cGKs) has been identified as an effector of cGMPinduced cytoskeletal changes in other cell types, we examined the role of cGKs in thyrocyte retraction by exposing HTU-5 cells to ANF in the presence and absence of the cGK inhibitor, KT5823 (Fig. 7). Results showed that KT5823 $(2 \mu \mathrm{M})$ did not significantly inhibit the increase in retracted cell number induced by ANF. Identical results were obtained in a separate study using a fivefold greater $(10 \mu \mathrm{M})$ concentration of KT5823 (data not shown).

\section{Discussion}

The first indication of a functional role for natriuretic peptides in the thyroid was the report of ANF suppression 


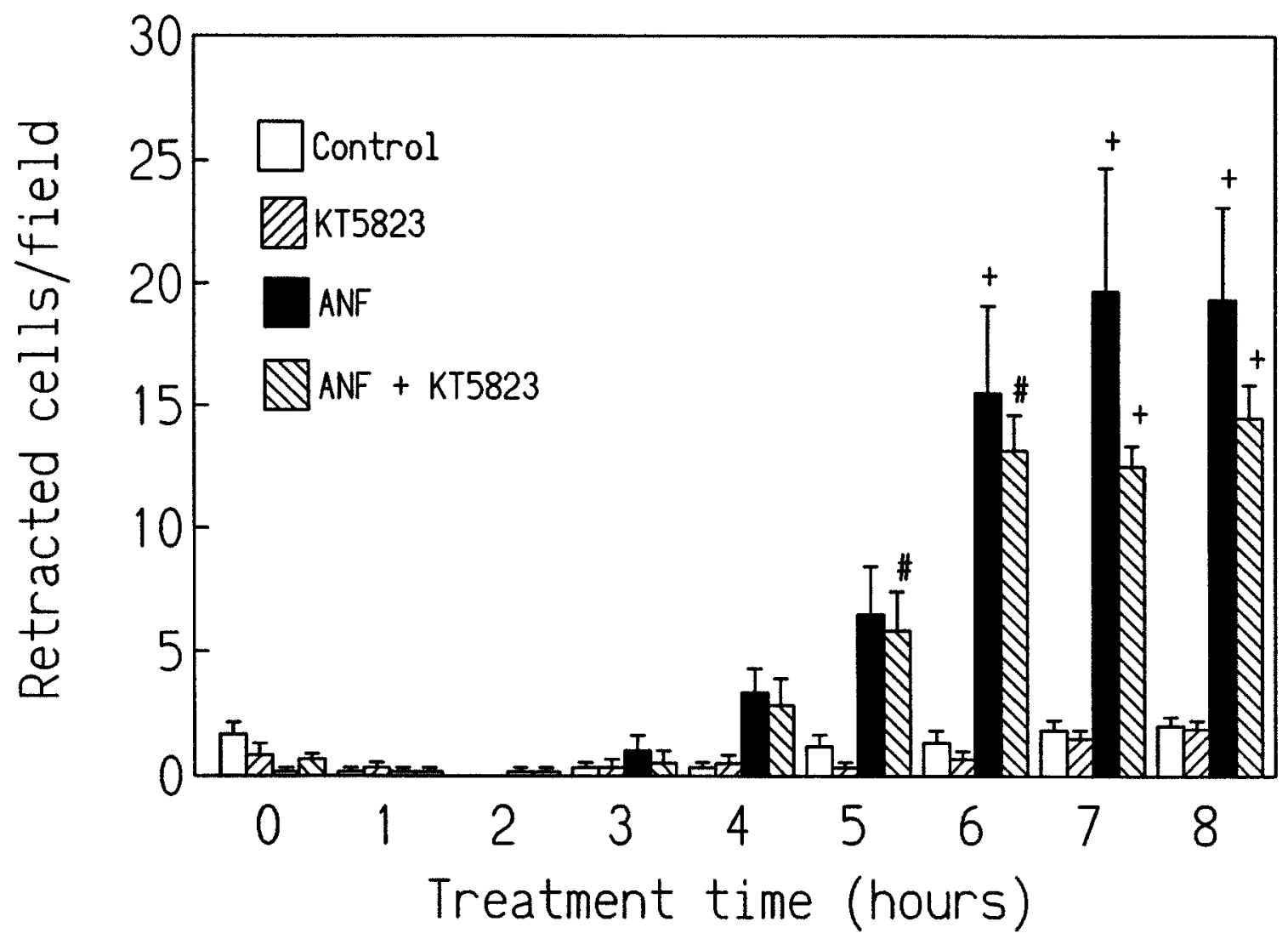

Figure 7 Effect of cGMP-dependent protein kinase inhibition on ANF-stimulated increase in numbers of retracted HTU-5 cells.

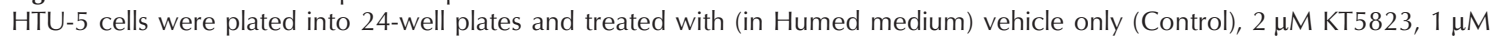
$\mathrm{ANF}$, or $1 \mu \mathrm{M}$ ANF $+2 \mu \mathrm{M}$ KT5823. Retracted cells were counted immediately (5 min) and at 1-h intervals for $8 \mathrm{~h}$ after treatment. Data represent \pm S.E.M. of six wells for each treatment group. Treatments were compared using non-parametric ANOVA and Dunn's Multiple Comparisons Test. $+P<0 \cdot 05, \# P<0 \cdot 01$ compared with control.

of thyroglobulin production in cultured human thyroid cells (Sellitti et al. 1989). Subsequently, the inhibition of thyroglobulin synthesis was shown to be closely correlated with a reduction in intracellular cAMP, the principal signaling pathway of the NPR-C receptor (Tseng et al. 1990). In contrast, the relatively modest response to ANF in cGMP stimulation, and the weak correlation of cGMP with thyroglobulin production have provided little support for guanylyl cyclase NPR function in the human thyroid cell (Tseng et al. 1990). In the present study, however, we have shown that ANF and CNP, but not the NPR-Cspecific ANF analog, C-ANF(4-23), markedly alter the morphology of human thyrocytes in culture, supporting a functional role for the guanylyl cyclase receptors, NPR-A and NPR-B, in the human thyroid. Semiquantitative PCR, moreover, confirmed that the guanylyl cyclase receptors are expressed both in the thyroid-derived cells and in the human thyroid.

The natriuretic peptides resemble TSH (Westermark \& Porter 1982) and the cytokine, interleukin-1 $\beta$ (Asakawa et al. 1996), in being thyroactive factors capable of inducing the retracted phenotype in cultured thyrocytes. As cell retraction has previously been established as a reflection of stress fiber (actin filament bundle) disintegration in human thyrocytes in culture (Westermark \& Porter 1982), we suggest that activation of the guanylyl cyclase receptors in thyroid cells may play a part in thyroid functions directly related to reorganization of the actin cytoskeleton. It is difficult to relate the retracted phenotype to a particular physiologic state of the follicular cell in vivo. This is especially true of HTU-5 cells, as this thyrocyte line has undergone a loss of several differentiated characteristics. Nonetheless, the downstream pathways leading to stress fiber disintegration remain intact and linked to signaling through natriuretic peptide receptors that are present in both these cells and the intact thyroid. Therefore, the natriuretic peptide-induced retraction might be expected to have functional correlates in the thyroid. The observation that the actin depolymerizing agent, cytochalasin $\mathrm{B}$, blocks colloid endocytosis in vivo (Williams \& Wolff 1971) suggests the possibility that natriuretic peptides could participate in the internalization 
of thyroglobulin. Other actin-dependent processes in which the natriuretic peptides could potentially participate in the thyroid cell include modulation of the number of microvilli (Asakawa et al. 1996), and cytoskeletondependent alterations in the pattern of gene expression (Lamy et al. 1990).

The effects of ANF and CNP on thyrocyte retraction were duplicated by the cGMP-mimetic compound 8-BrcGMP, but not by the NPR-C specific ANF analog, C-ANF(4-23), suggesting that the generation of an intracellular cGMP signal is very probably a key event in altering the morphology of the follicular cell. ANFmediated cell retraction has been observed previously in endothelial cells (Lofton et al. 1991), and the ANF/GMP signal pathway has been shown to transduce actin fiber disassembly in the endothelial cell type and others (Smolenski et al. 2000, Sharma et al. 1992). Although previous investigations in human endothelial cells (Sharma et al. 1992) and rat neointimal cells (Monks et al. 1998) suggest that cGMP-induced actin reorganization could be mediated by activation of cGMP-dependent protein kinase, inactivation of cGK by KT5823 did not significantly alter the ability of ANF to induce thyrocyte retraction. These results suggest that other effectors of cGMP signaling, including either cGMP-gated channels or cGMP-regulated phosphodiesterases, could transmit the signal for cytoskeletal changes downstream of ANF binding in the cultured thyrocytes.

ANF- and CNP-stimulated cGMP generation assays suggest that initial densities of functional NPR-A and NPR-B in HTU-5 cells were roughly equivalent. However, the markedly different long-term response to ANF and CNP respectively, suggests a differential desensitization, or down-regulation, of the guanylyl cyclases by the natriuretic peptides themselves, with NPR-A declining rapidly in activity, but NPR-B declining at a much slower rate after continuous treatment with their respective ligands. Homologous desensitization of NPR-A by ANF has been shown previously (Potter \& Garbers 1992), as has homologous desensitization of NPR-B by CNP (Potter 1998, Fowkes et al. 2000), and with both receptors involves a rapid dephosphorylation of the receptor protein after natriuretic peptide binding. NPR-A does not appear to be down-regulated in cultured cells via ligand-induced receptor internalization or degradation (Potter \& Garbers 1994); however, several studies have demonstrated the ligand-dependent down-regulation of NPR-A (Cao et al. 1998) gene expression. In addition, a previous investigation has demonstrated the transcriptional down-regulation of both NPR-A and NPR-B by ANF (Vera et al. 2000), although the autologous regulation of NPR-B transcription by CNP has not, to our knowledge, been reported. The desensitizing effects of the natriuretic peptides on their respective receptors appear to be too rapid to explain the gradual loss of ANF and CNP induction of cell retraction. Instead, autologous down-regulation of cell-surface NPR by ANF and CNP represents a better explanation of the present results, with the more rapid down-regulation of NPR-A than of NPR-B reflecting a differential regulation of their transcription. A physiologic role for the differences between NPR-A and NPR-B regulation in the human thyrocyte is yet to be determined, but it could reflect the sorting of an endocrine signal (primarily ANF) (Hama et al. 1994) from an autocrine/paracrine signal produced by endogenous thyroid CNP (Sellitti \& Doi 1999).

\section{Conclusions}

We have shown that ANF and CNP induce morphologic changes in human thyroid cells mediated through NPR-A and NPR-B. In addition, we have shown for the first time that transcripts for these receptors are expressed both in cultured thyroid cells and in whole human thyroid. The full range of guanylyl cyclase NPR functions in thyroid cells remains to be determined, but additional roles for NPR-A and NPR-B are suggested by studies of cGMP generated by alternate means. Bocanera et al. (1997) demonstrated that activation of the soluble guanylyl cyclase-cGMP pathway by nitric oxide in bovine thyroid cells significantly inhibits iodide uptake. Costamagna et al. (1998), similarly, have observed a significant inhibition of iodide organification in bovine thyroid cells in the presence of dibutyryl cGMP. These findings support the concept that not only NPR-C, but also the guanylyl cyclases NPR-A and NPR-B, may be involved in the regulation of the thyroid hormone biosynthetic pathway and other functions of the human thyroid follicular cell.

\section{References}

Anand-Srivastava MB \& Trachte GJ 1993 Atrial natriuretic factor receptors and signal transduction mechanisms. Pharmacological Reviews 45 455-497.

Asakawa H, Miyagawa J-I, Kobayashi T, Hanafusa T, Kuwajima M \& Matsuzawa Y 1996 Effects of interleukin-1 $\beta$ on scanning electron microscopic appearance and thyroid peroxidase content of human thyrocytes in monoloayer culture. Immunopharmacology 34 131-137.

Bidey SP, Hill DJ \& Eggo MC 1999 Growth factors and goitrogenesis. Journal of Endocrinology 160 321-332.

Bocanera LV, Krawiec L, Silberschmidt D, Pignataro O, Juvenal GJ, Pregliasco LB \& Pisarev MA 1997 Role of cyclic 3'5'guanosine monophophate and nitric oxide in the regulation of iodide uptake in calf thyroid cells. Journal of Endocrinology 155 451-457.

Cao L, Chen SC, Cheng T, Humphreys MH \& Gardner DG 1998 Ligand-dependent regulation of NPR-A gene expression in inner medullary collecting duct cells. American Journal of Physiology 275 F119-F125.

Chinkers M, Garbers DL, Chang M-S, Lowe DG, Chin H, Goeddel DV \& Schultz S 1989 A membrane form of guanylate cyclase is an atrial natriuretic peptide receptor. Nature 338 78-83.

Costamagna ME, Cabanillas AM, Coleoni AH, Pellizas CG \& Masini-Repiso AM 1998 Nitric oxide donors inhibit iodide transport and organification and induce morphological changes in cultured bovine thyroid cells. Thyroid 8 1127-1135. 
Curcio F, Ambesi-Impiombato FS, Perrella G \& Coon HG 1994 Long-term culture and functional characterization of follicular cells from adult normal human thyroids. PNAS 91 9004-9008.

Eggo MC \& Sheppard MC 1994 Autocrine growth factors produced in the thyroid. Molecular and Cellular Endocrinology 100 97-102.

Fowkes RC, Forrest-Owen W \& McArdle CA 2000 C-Type natriuretic peptide (CNP) effects in anterior pituitary cell lines: evidence for homologous desensitization of CNP-stimulated cGMP accumulation in aT3-1 gonadotroph-derived cells. Journal of Endocrinology 166 195-203.

Fuller F, Porter JG, Arfsten AE, Miller J, Schilling JW, Scarborough RM, Lewicki JA \& Schenk DB 1988 Atrial natriuretic peptide clearance receptor. Complete sequence and functional expression of cDNA clones. Journal of Biological Chemistry 253 9395-9401.

Garbers DL \& Lowe DG 1994 Guanylyl cyclase receptors. Journal of Biological Chemistry 269 741-744.

Giles KW \& Ayers A 1965 An improved diphenylamine method for the estimation of deoxyribonucleic acid. Nature 497993.

Hama N, Itoh H, Shirakami G, Suga S, Komatsu Y, Yoshimasa T, Tanaka I, Mori K \& Nakao K 1994 Detection of C-type natriuretic peptide (CNP) in human circulation and marked increase of plasma CNP level in septic shock patients. Biochemical and Biophysical Research Communications 198 1177-1182.

Hughes CE \& Sellitti DF 1991 Thyroidal ANF: a possible mediator of autocrine regulation in the porcine thyroid gland. Peptides $\mathbf{1 2}$ 705-714.

Koller KJ, Lowe DG, Bennett GL, Minamino N, Kangawa K, Matsuo H \& Goeddel DV 1991 Selective activation of the B natriuretic peptide receptor by C-type natriuretic peptide (CNP). Science 252 $120-123$.

Lamy F, Taton M, Dumont JE \& Roger PP 1990 Control of protein synthesis by thyrotropin and epidermal growth factor in human thyrocytes: role of morphological changes. Molecular and Cellular Endocrinology 73 195-209.

Levin ER, Gardner DG \& Samson WK 1998 Natriuretic peptides. New England Journal of Medicine 339 321-328.

Lofton CE, Baron DA, Heffner JE, Currie MG \& Newman WH 1991 Atrial natriuretic peptide inhibits oxidant-induced increases in endothelial permeability. Journal of Molecular and Cellular Cardiology 23 919-927.

Lowe DG, Chang MS, Hellmiss R, Chen E, Singh S, Garbers DL \& Goeddel DV 1989 Human atrial natriuretic peptide receptor defines a new paradigm for second messenger signal transduction. EMBO Journal 8 1377-1384.

Monks D, Lange V, Silber RE, Markert T, Walter U \& Nehls V 1998 Expression of cGMP-dependent protein kinase I and its substrate VASP in neointimal cells of the injured rat carotid artery. European Journal of Clinical Investigation 28 416-423.

Murthy KS \& Makhlouf GM 1999 Identification of the G protein-activating domain of the natriuretic peptide clearance receptor (NPR-C). Journal of Biological Chemistry 274 17587-17592.

Potter LR 1998 Phosphorylation-dependent regulation of the guanylyl cyclase-linked natriuretic peptide receptor B: dephosphorylation is a mechanism of desensitization. Biochemistry 8 2422-2429.

Potter LR \& Garbers DL 1992 Dephosphorylation of the guanylyl cyclase-A receptor causes desensitization. Journal of Biological Chemistry 267 14531-14534.

Potter LR \& Garbers DL 1994 Protein kinase C-dependent desensitization of the atrial natriuretic peptide receptor is mediated by dephosphorylation. Journal of Biological Chemistry 269 14636-14642.

Rasmussen AK, Diamant M, Blichert-Toft M, Bendtzen K \& Feldt-Rasmussen U 1997 The effects of interleukin-1 $\beta$ (IL-1 $\beta$ ) on human thyrocyte functions are counteracted by the IL-1 receptor antagonist. Endocrinology 138 2043-2048.
Schultz S, Singh S, Bellet RA, Singh G, Tubb DJ, Chin H \& Garber DL 1989 The primary structure of a plasma membrane guanylate cyclase demonstrates diversity within this new receptor family. Cell 58 1155-1162.

Sellitti DF \& Doi SQ 1994 C-Type natriuretic peptide (CNP) increases $\left[{ }^{125} \mathrm{I}\right]$ ANF binding to FRTL-5 thyroid cells by increasing ANF receptor affinity. Peptides 15 1249-1253.

Sellitti DF \& Doi SQ 1999 Regulation of natriuretic peptide receptors by thyrotropin in FRTL-5 rat thyroid cells: evidence for nonguanylate cyclase atrial natriuretic factor-binding sites in cells lacking the natriuretic peptide receptor C. Endocrinology 140 1365-1374.

Sellitti DF \& Hughes CE 1990 Immunoreactive atrial natriuretic peptide in the thyroid gland. Regulatory Peptides 27 285-298.

Sellitti DF, Tseng Y-CL \& Wartofsky L 1989 Receptors for atrial natriuretic peptide (ANP) and regulation of thyroglobulin secretion by ANP in human thyroid cells. Life Sciences $4 \mathbf{5}$ 793-801.

Sellitti DF, Hughes CE, Hensen SA \& Vincent MM 1992 Secretion of immunoreactive ANF from FRTL-5 rat thyroid cells: regulation by calcium ionophore A23187. Regulatory Peptides 41 257-273.

Sellitti DF, Hill R, Doi SQ, Akamizu T, Czaja J, Tao S \& Koshiyama H 1997 Differential expression of thyrotropin receptor mRNA in the porcine heart. Thyroid 7 641-646.

Sellitti DF, Akamizu T, Doi SQ, Kim GH, Kariyil JT, Kopchik JJ \& Koshiyama H 2000 Renal expression of two 'thyroid-specific' genes: thyrotropin receptor and thyroglobulin. Experimental Nephrology 8 235-243.

Sellitti DF, Perrella G, Doi SQ \& Curcio F 2001 Natriuretic peptides increase cAMP production in human thyrocytes via the natriruetic peptide clearance receptor. Regulatory Peptides 97 103-109.

Sharma R, Lovell HB, Wiegmann TB \& Savin VJ 1992 Vasoactive substances induce cytoskeletal changes in cultured rat glomerular epithelial cells. Journal of the American Society of Nephrology 3 1131-1138.

Smolenski A, Poller W, Walter U \& Lohmann SM 2000 Regulation of human endothelial cell focal adhesion sites and migration by cGMP-dependent protein kinase I. Journal of Biological Chemistry 275 25723-25732.

Taton M, Lamy F, Roger PP \& Dumont JE 1993 General inhibition by transforming growth factor $\beta 1$ of thyrotropin and cAMP responses in human thyroid cells in primary culture. Molecular and Cellular Endocrinology 95 13-21.

Trusolino L, Serini G, Cecchini G, Besati C, Ambesi-Impiombato FS, Marchisio PC \& De Filippi R 1998 Growth factor-dependent activation of alphavbeta 3 integrin in normal epithelial cells: implications for tumor invasion. Journal of Cellular Biology 142 $1145-1156$

Tseng Y-CL, Lahiri S, Sellitti DF, Burman KD, D’Avis JC \& Wartofsky L 1990 Characterization by affinity cross-linking of a receptor for atrial natriuretic peptide in cultured human thyroid cells associated with reductions in both adenosine $3^{\prime}, 5^{\prime}-$ monophosphate production and thyroglobulin secretion. Journal of Clinical Endocrinology and Metabolism 70 528-533.

Vera N, Tse MY, Watson JD, Sarda S, Steinhelper ME, John SW, Flynn TG \& Pang SC 2000 Altered expression of natriuretic peptide receptors in proANP gene disrupted mice. Cardiovascular Research 46 595-603.

Westermark B \& Porter KR 1982 Hormonally induced changes in the cytoskeleton of human thyroid cells in culture. Journal of Cellular Biology 94 42-50.

Williams JA \& Wolff J 1971 Cytochalasin inhibits thyroid secretion. Biochemical and Biophysical Research Communications 44 422-425.

Received 22 October 2001

Accepted 28 November 2001 